\title{
1 Diversity of foraging strategies and responses to predator 2 interference in seed-eating carabid beetles
}

3

4

5 Alice Charalabidis ${ }^{\mathrm{a}, \mathrm{b}}$, François-Xavier Dechaume-Moncharmont ${ }^{\mathrm{b}}$, Benjamin Carbonne ${ }^{\mathrm{a}}$,

6 David A. Bohan ${ }^{a} \&$ Sandrine Petit *a

7

8 a Agroécologie, AgroSup Dijon, INRA, Univ. Bourgogne Franche-Comté, F-21000 Dijon,

9 France

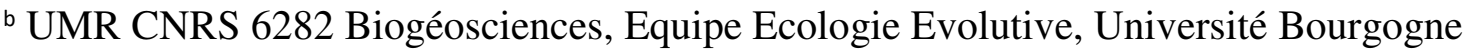

Franche-Comté, 6 bd Gabriel, 21000 Dijon, France

*Corresponding author. Tel.: +33380693032.

E-mail address: sandrine.petit-michaut@inra.fr. 


\section{Abstract}

The prediction of pest regulation by multi-predator communities often remains challenging because of variable and opposite effects of niche complementarity and predator interference. Carabid communities are regulating weeds in arable fields and include a mix of species ranging from granivores to predators that are obligate omnivores. It is not clear from field studies whether granivore and obligate omnivore species either contribute equally or are complementary in the process of weed suppression, and little is known about the impact of potential predator interference within carabid communities on weed suppression. We compared the weed seed foraging strategy of the granivore Harpalus affinis and the obligate omnivore Poecilus cupreus. Using no-choice test experiments, we compared their activity and seed acceptance for four weed species through a scoring of the proportion of tested individuals consuming weeds, their latency before the consumption of the first seed and the total number of seeds consumed. We then evaluated their seed acceptance for dandelion seed Taraxacum officinale under predator interference by using chemical cues of carabids and tested the impact of three treatments, namely cues of intraspecific competition, interspecific competition and intraguild predation. We found that the obligate omnivore $P$. cupreus was highly active, had a low latency before consuming its first seed but had an interest in only two of the four weed species. $P$. cupreus seed acceptance remained unchanged in the presence of predator cues. By contrast, $H$. affinis was slow to start its seed consumption, accepted equally seeds of the four weed species and significantly increased its seed consumption in the presence of cues mimicking intraguild predation. These findings indicate that the two species differ in their foraging strategies, and as such, could have different contributions to weed seed suppression. This novel result calls for further studies documenting the foraging strategy of carabid species that thrive in arable fields as this could significantly improve our understanding of the delivery of weed seed regulation. 
43 Keywords: Weed regulation; trophic guild; seed acceptance; latency; predation risk;

44 competition.

45 


\section{Introduction}

The prediction of pest regulation by multi-predator communities remains difficult, notably because of the variable effects, both positive and negative, of generalist predator diversity on biocontrol that can arise either from predator niche complementarity or from predator interference (Crowder \& Jabbour, 2014; Straub, Finke, \& Snyder, 2008; Tylianakis \& Romo, 2010). Assessing the relative importance of both processes within predator communities could provide an explanatory mechanism for a relationship between predator diversity and the ecosystem function of biological control (Hines, van der Putten, De Deyn, Wagg, Voigt, et al., 2015; Loreau, 2001).

Seed-eating carabid beetles are common and abundant predators that contribute to weed control in arable fields (Bohan, Boursault, Brooks, \& Petit, 2011; Kulkarni, Dosdall, \& Willenborg, 2015). Differences in the relative importance of plant vs. animal prey in their diet mean that species can be placed along a continuum between more granivorous species that only feed occasionally on animal prey (i.e. opportunistic omnivores) to predators feeding both on plant and animal food (i.e. obligate omnivores) (Deroulers \& Bretagnolle, 2018; Hengeveld, 1979). Granivore and obligate omnivore species coexist within carabid communities of arable fields, but the relative contribution of species exhibiting one diet or the other to weed suppression has not yet been resolved. Field studies analysing the links between carabid communities and co-occurring rates of seed predation have produced equivocal results. Some field studies demonstrated strong relationships between total seed-eating carabid abundance and seed predation rates (Menalled, Smith, Dauer, \& Fox, 2007; O’Rourke, Heggenstaller, Liebman, \& Rice, 2006; Petit, Trichard, Biju-Duval, McLaughlin, \& Bohan, 2017), suggesting that granivore and obligate omnivore species might contribute relatively equally to weed regulation and that predator interference is of limited importance.

Other studies have highlighted the major role of granivore abundance (Diekötter, Wamser, 
Dörner, Wolters, \& Birkhofer, 2016; Trichard, Alignier, Biju-Duval, \& Petit, 2013) or, conversely, of obligate omnivore abundance (Bohan et al., 2011; Jonason, Smith, Bengtsson, \& Birkhofer, 2013). There is also field evidence that carabid species richness and/or diversity can be better predictors of seed predation rates than carabid abundances (Gaines \& Gratton, 2010; Jonason et al., 2013; Trichard et al., 2013), suggesting that there could be some level of complementarity between carabid species in weed regulation. These apparent contradictory findings might result from context-dependency, being determined by the composition of the carabid communities and the focal weed prey species. If we are to manage arable systems to promote weed regulation through changes in carabid communities, it appears necessary to clarify the relative contribution of granivore and obligate omnivore species to seed predation. In controlled conditions, two key specific aspects may affect weed seed acceptance by a carabid species. First, one can hypothesise that an obligate omnivore species has a metabolic physiology that is not well adapted to the consumption and digestion of many different species of weed seeds (Lundgren \& Lehman, 2010) even if it requires seeds as food to increase its fitness (Kulkarni et al., 2015; Saska \& Jarošík, 2001). By contrast, a granivore species, being well-adapted to digesting plant material, might accept a wider range of weed seed species than an obligate omnivore species. Second, several studies indicate that predator interference is common among seed-eating carabid species, as evidenced in several studies using either true individuals (Griffith \& Poulson, 1993; Currie et al., 1996) or chemical cues (Charalabidis, Dechaume-Moncharmont, Petit, \& Bohan, 2017; Guy, Bohan, Powers, \& Reynolds, 2008) to mimic predator interference. This might mean that the effort and time that an individual will invest in foraging for an acceptable feeding item will change according to the perceived intensity and risk of predator interference (Amita, Kawamori, \& Matsushima, 2010; Davis, Nufio, \& Papaj, 2011; Dechaume-Moncharmont, Brom, \& Cézilly, 2016; Ibrahim \& Huntingford, 1989; Jennions \& Petrie, 1997; Metcalfe, Huntingford, \& Thorpe, 
1987). The impact of predator interference on prey consumption in carabids has rarely been documented and existing studies have produced equivocal results. Predator interference has been found to reduce per capita consumption of animal prey by carabids (Griffith \& Poulson, 1993; B. Lang, Rall, \& Brose, 2012), while predation risk has been shown to increase the consumption of weed seeds by carabids (Charalabidis et al., 2017) and vertebrate predators (Blubaugh, Widick, \& Kaplan, 2017).

In this study, our aim was to investigate the existence of distinct foraging strategies in seed-eating carabids. Using no-choice experiments in laboratory microcosms, we characterised the foraging strategies of two seed-eating carabid species common in European arable fields, the granivore Harpalus affinis (Fabricius, 1775) and the obligate omnivore Poecilus cupreus (Linnaeus, 1758). In our first experiment, we estimated seed acceptance in pairwise combinations of the two carabid species and four model weed species. We scored the proportion of individuals consuming weeds, individual latency to first seed acceptance, counts of seeds consumed and shelter use over 1 hour and, additionally, counts of seeds consumed and shelter use after 13 hours. We expected the two carabid species to differ in their pattern of seed acceptance. In our second experiment, we evaluated the impact of predator or competitor cues on seed acceptance of the two carabid species for seeds of $T$. officinale by comparing seed acceptance during 1 hour under four treatment levels, i.e. no predator or competitor cues (control), intraspecific competition cues, interspecific competition cues and intraguild predation cues. Here we, expected the two carabid species to differ in their response to predator and competitor cues.

\section{Materials and Methods}

\section{The study system}


The obligate omnivore, $P$. cupreus ( 11-12 mm), and the granivorous $H$. affinis ( 9$12 \mathrm{~mm}$ ), are both medium-sized spring-breeding carabids that are common in arable fields. The four weed species, Capsella bursa-pastoris (L.) Medik. (dry weight $0.1 \mathrm{mg}$, length 0.8 $\mathrm{mm})$, Senecio vulgaris L. (0.2 mg, $1.75 \mathrm{~mm})$, Taraxacum officinale Weber $(0.7 \mathrm{mg}, 2.67$ $\mathrm{mm})$, Viola arvensis Murray $(0.9 \mathrm{mg}, 1.36 \mathrm{~mm})$ were collected locally. These weeds are common in farmland and readily consumed by both carabid species, both in field and laboratory conditions (Petit, Boursault, \& Bohan, 2014; Trichard, Ricci, Ducourtieux, \& Petit, 2014). For the experiments using predator and competitor cues, the granivorous Pseudoophonus rufipes (De Geer 1774, 11-16 mm) was chosen as the competitor species for both our focal species while Pterostichus melanarius (Illiger 1798, 12-19 mm), an obligate omnivore which also preys on other carabids (Currie, Spence, \& Niemelä, 1996) was chosen as the predator species.

Carabids were collected from traps, placed in rearing boxes and reared in controlled conditions $\left(19{ }^{\circ} \mathrm{C}+/-1{ }^{\circ} \mathrm{C}, 60 \%\right.$ humidity, $14: 10$ light:dark cycle). The rearing boxes were filled with field soil and a moistened paper tissue sheet. Water was provided ad libitum in an Eppendorf tube containing moistened cotton wool. The carabid species were held in separate boxes to prevent interspecific predation (Currie et al., 1996). At least 2 weeks prior to experimentation the boxes were moved to different rooms to prevent exposure and habituation to interspecific chemical signatures. Individuals were fed with the four tested weed seed species and the obligate omnivores were presented with Tenebrio molitor larva and frozen beef as an additional meat diet. Individuals were starved for 54 hours prior to testing to produce individuals motivated to feed. Preliminary experimentation had shown that the 54 hours duration did not affect survival or locomotory behaviours. 
All seeds used in the experiments were soaked in clean water for 14 hours prior to each experimental test, to become more palatable to and detectable by carabids (Law \& Gallagher, 2015).

\section{General experimental design}

We used no-choice tests, where only one seed species was presented to individuals (Dougherty \& Shuker, 2014). No-choice tests are widely used in behavioural ecology and assess the absolute acceptance level of a food item (Jennions \& Petrie, 1997; Murray, Withers, \& Mansfield, 2010; Reinhold \& Schielzeth, 2014; Rodríguez \& Greenfield, 2003; Rothbart \& Hennig, 2012). This method was selected over choice tests (cafeteria tests) because these only provide comparative estimates of acceptance of a food item. The experimental methodology of choice tests can artificially decrease or increase the attractiveness of a given food item, through a contrast effect with other items offered simultaneously (Dougherty \& Shuker, 2014; Edward, 2014; Larrinaga, 2010; Murray et al., 2010; Raffa, Havill, \& Nordheim, 2002; Underwood, Chapman, \& Crowe, 2004). humidity. Each individual was tested alone and once. To avoid a potential effect of date / hour and the status of individuals, all treatments and both sexes were tested each day in a random order. To avoid any possible behavioural modification via volatile olfactory cues, the two carabid species were always tested on separate days. 
Individuals were placed in small plastic arenas $(9 \times 5 \mathrm{~cm}$ diameter $\mathrm{x}$ height $)$ which contained a moist paper tissue (hiding place), water provided ad libitum and 20 seeds evenly positioned and were monitored for 13 hours. We tested a total of $80 \mathrm{H}$. affinis and $72 \mathrm{P}$. cupreus, respectively. The number of males and females tested for each weed species is presented in Table 1.

During the first hour, we recorded: (i) the proportion of individuals eating; (ii) the latency to first seed acceptance, as the time from the first movement of an individual until it accepts the first seed; (iii) the number of seeds consumed; and, (iv) individual shelter usage, as the total number of sampling time points where individuals were under the moist paper tissue (head not visible). In addition, the number of seeds consumed and individual shelter usage were recorded at $2 \mathrm{~h}, 3 \mathrm{~h}, 4 \mathrm{~h}, 5 \mathrm{~h}$, and $13 \mathrm{~h}$. Damaged seeds and the debris from eaten seeds were removed at each sampling time point to avoid double accounting.

\section{Statistical analysis}

The proportion of individuals eating and/or using a shelter (i.e shelter usage) were modelled with generalized linear models using a binomial distribution. If the seed species effect was significant, the difference between seed species was analysed using exact Fisher's test for the null hypothesis of odds-ratio $\mathrm{OR}=1$ based on the 'twoby2' function from 'Epi' package (Carstensen et al., 2017). Latency to first seed acceptance was analysed using Cox proportional hazard models in the 'cox.ph' function from the 'survival' package (Therneau, 2015) and effect size indices and the corresponding 95\% confidence intervals reported to allow meta-analysis or comparisons in future studies (Lakens, 2013; Nakagawa \& Cuthill, 2007). The measure of effect size for all latencies was the hazard ratio estimated as the exponential of the regression coefficient, $\exp ($ beta), of the Cox model (Dechaume Moncharmont, Decourtye, Hennequet-Hantier, Pons, \& Pham-Delègue, 2003). The total 
number of seeds consumed was analysed using beta regressions with the function 'betareg' from the 'betareg' package (Cribari-Neto \& Zeileis, 2010). If the weed species effect was significant, differences between specific pairs of weeds were tested using post-hoc multiple comparisons with Tukey adjustment. Data were analysed in R version 3.3.2 (R Development Core Team, 2016).

\section{Effect of predator and competitor cues on seed acceptance}

\section{Experimental setting}

The experiment was conducted on $P$. cupreus and results were compared with those obtained for H. affinis, reported in Charalabidis et al. (2017). Using the method of Armsworth et al. (2005), predators and competitors were simulated with chemical cues. It has been shown that walking carabids leave olfactory cues along their path of movement and that these cues can induce behavioural change in carabids and in their prey (Armsworth, Bohan, Powers, Glen, \& Symondson, 2005; Charalabidis et al., 2017; Guy et al., 2008). This method was preferred over the use of actual competitors or predators which would have not allowed to separate the weed seed consumption of the focal individual from that of the competitor or predator. Moreover, mating-related behaviours, which might have occurred in the intraspecific competition treatment, or predatory interactions, which might have occurred in the predation treatment, would have distracted individuals from foraging.

Predator and competitor cues were simulated by placing in the arena a white filter paper impregnated with non-volatile cuticular carabid hydrocarbon chemical cues using the method of Armsworth et al., (2005). To produce an appropriate level of stimulus on the filter paper (Guy et al., 2008), 20 carabids (10 females and 10 males) were released to walk over the papers for 24h (Armsworth et al., 2005). Chemical cues from either H. affinis or P. cupreus, 
or $P$. rufipes or $P$. melanarius were used to simulate respectively intraspecific competition, interspecific competition and intraguild predation. For the control treatment clean test papers, with no carabid chemical cues, were used.

Individuals were tested in $18 \mathrm{~cm}$ diameter arenas, namely a petri dish positioned on the filter paper on which 20 seeds of $T$. officinale were arranged in two concentric circles of 10 seeds of respectively 5 and $16 \mathrm{~cm}$ diameter.

As experiments were conducted during the reproductive season of carabids, cues left by conspecifics on the impregnated paper of the intraspecific competition treatment could also be perceived as sexual olfactory cues and could induce mating-related behaviours and distract individuals from foraging. In order to disentangle the behaviours due to perceived food competitors from those due to perceived sexual competitors, we treated interspecific competition as a control for these potential sexual olfactory interactions. Test individuals were placed under a plastic pot at the centre of the arena for 8 min prior to the start of each replicate test, the pot was then removed and the test individuals were observed and filmed for one hour using a monochrome video camera (Imaging Source DMK 31AU03) suspended over the arena. A total of 287 P. cupreus individuals were split into four treatment groups: control, intraspecific competition, interspecific competition and predation. Results were compared to those obtained with $290 \mathrm{H}$. affinis individuals split into similar groups and reported in Charalabidis et al. (2017). The numbers of males and females tested in each treatment are presented in Table 2.

After 1h, seed acceptance was assessed by scoring: i) the proportion of individuals that had consumed at least one seed; ii) the latency to first seed acceptance; and, iii) the number of seeds consumed. The videos were used to score seed handling time, measured as the duration of consumption of a single seed, and individual space use evaluated in Ethovision (Noldus 
Information Technology, Wageningen, The Netherlands) as the number of 1 x $1 \mathrm{~cm}$ cells of the arena visited at least once.

\section{Statistical analyses}

Latency to first seed acceptance and seed handling time were analysed, as before, using the Cox proportional hazard models. The total number of seeds consumed was modelled as a generalized linear model assuming a negative binomial distribution with zero-inflation, in the 'zeroinfl' function from the 'pscl' package (Jackman, 2015). Individual space use was analysed using ANOVA. For each analysis, sex effect and treatment interactions were tested. Data were analysed in R version 3.3.2 (R Development Core Team, 2016).

\section{Results}

\section{Acceptance of weed seeds without olfactory disturbance}

Estimates for the variables recorded during the first hour of the experiment are presented in Table 1. Potential sex effects and of interactions between sex and weed species are presented in the appendices (see Appendix A: Table 1) and are mentioned in the text where the results are significant.

For $P$. cupreus, the proportion of individuals consuming seeds differed between weed species $\left(\chi^{2}=24.41, \mathrm{df}=3, \mathrm{P}<0.001\right)$ and was lower for $C$. bursa-pastoris than for $S$. vulgaris $(\mathrm{P}=0.016)$, . officinale $(\mathrm{P}=0.0042)$ and $V$. arvensis $(\mathrm{P}=0.002)$ (see Appendix A: Table 2). Individuals accepted their first seed of C. bursa-pastoris significantly later than in S. vulgaris $(\mathrm{P}=0.0085)$, T. officinale $(\mathrm{P}<0.001)$ and $V$. arvensis $(\mathrm{P}<0.001)$ (see Appendix A: Table 3). 
The amount of seeds consumed differed between weed species during the first hour $\left(\chi^{2}=\right.$ 11.58, df $=3, \mathrm{P}=0.0090$, Fig. 1), with more T. officinale consumed than C. bursa-pastoris ( $\mathrm{P}$ $=0.013$, see Appendix A: Table 4). There was also a significant difference at 13 hours $\left(\chi^{2}=\right.$ 41.17, df =3, P <0.001, Fig. 1) for pairs of weed species (see Appendix A: Table 4). T. officinale was consumed more than $C$. bursa pastoris $(\mathrm{P}<0.001)$ and $V$. arvensis $(\mathrm{P}<0.001)$ while $S$. vulgaris was consumed more than $C$. bursa-pastoris $(\mathrm{P}<0.001)$ and $V$. arvensis $(\mathrm{P}=$ 0.001). Females used the shelter more than males $\left(\chi^{2}=8.45\right.$, $\left.\mathrm{df}=1, \mathrm{P}=0.0036\right)$ and shelter usage was not affected by the weed species $\left(\chi^{2}=1.26\right.$, $\left.\mathrm{df}=3, \mathrm{P}=0.74\right)$, with no interaction between weed species and sex of individuals $\left(\chi^{2}=5.76, \mathrm{df}=3, \mathrm{P}=0.12\right)$.

For $H$. affinis, the weed species did not affect either the proportion of individuals eating $\left(\chi^{2}=1.33\right.$, df $\left.=3, P=0.72\right)$, the latency to first seed consumption $\left(\chi^{2}=1.56, \mathrm{df}=3, \mathrm{P}=\right.$ 0.67 , or the mean amount of seeds consumed in the first hour $\left(\chi^{2}=0.66, \mathrm{df}=3, \mathrm{P}=0.88\right.$, Fig. 1) and at 13 hours $\left(\chi^{2}=4.74\right.$, df $=3, P=0.19$, Fig. 1$)$. Females used the shelter more than males $\left(\chi^{2}=54.12, \mathrm{df}=1, \mathrm{P}<0.001\right)$ and shelter usage was not affected by the weed species $\left(\chi^{2}\right.$ $=2.04, \mathrm{df}=3, \mathrm{P}=0.56)$ with no interaction between weed species and sex of individuals $\left(\chi^{2}=\right.$ 2.83, df $=3, \mathrm{P}=0.42$ ).

The two carabid species differed in their seed acceptance for the four weed species in the first hour and at 13 hours. In the first hour, the proportion of individuals of P. cupreus that had consumed $S$. vulgaris $\left(\chi^{2}=7.64, \mathrm{df}=1, \mathrm{P}=0.0057\right)$, V. arvensis $\left(\chi^{2}=17.21, \mathrm{df}=1, \mathrm{P}<0.001\right)$ and T. officinale $\left(\chi^{2}=23.33\right.$, df $\left.=1, \mathrm{P}<0.001\right)$ was higher than that of $H$. affinis. The two carabid species differed in their latency to first seed acceptance $\left(\chi^{2}=48.77\right.$, df $\left.=1, \mathrm{P}<0.001\right)$ with $P$. cupreus accepting the first seed earlier than $H$. affinis for the four weed species (hazard ratio for $P$. cupreus compared with $H$. affinis $=6.1,95 \% \mathrm{CI}=[3.52,10.60], \mathrm{P}<$ 0.001). At the end of the experiment, $H$. affinis had consumed more weed seeds than $P$. cupreus $\left(\chi^{2}=17.67, \mathrm{df}=1, \mathrm{P}<0.001\right)$, with mean amounts of 14.6 and 11 seeds at 13 hours, 
respectively. The two carabids also differed in their mean consumption of specific weed seeds $\left(\chi^{2}=9.08, \mathrm{df}=3, \mathrm{P}=0.028\right)$. Harpalus affinis consumed more seeds of $C$. bursa-pastoris $\left(\chi^{2}=\right.$ 20.72, df $=1, \mathrm{P}<0.001)$ and V. arvensis $\left(\chi^{2}=12.17\right.$, df $\left.=1, \mathrm{P}<0.001\right)$ than $P$. cupreus. Conversely, $P$. cupreus consumed more seeds of $T$. officinale $\left(\chi^{2}=16.37\right.$, $\left.\mathrm{df}=1, \mathrm{P}<0.001\right)$ than $H$. affinis. The two carabid species did not differ in their mean consumption of $S$. vulgaris $\left(\chi^{2}=0.23, \mathrm{df}=1, \mathrm{P}=0.63\right)$. Harpalus affinis females $\left(\chi^{2}=156.33, \mathrm{df}=1, \mathrm{P}<0.001\right)$ and males $\left(\chi^{2}=71.55\right.$, df $\left.=1, \mathrm{P}<0.001\right)$ used the shelter more often than $P$. cupreus individuals.

\section{Effect of predator and competitor cues on seed acceptance}

Variable estimates per carabid species and sex for each treatment are presented in Table 2. Results for potential sex effect and interactions between sex and the treatments are presented in Appendix A: Table 5.

For $P$. cupreus, irrespective of treatment, the proportion of males consuming seeds was higher than that of females $\left(\chi^{2}=4.1, \mathrm{df}=1, \mathrm{P}=0.04\right)$. Females accepted their first seed later $\left(\chi^{2}=8.09, \mathrm{df}=1, \mathrm{P}=0.004\right)$, consumed seeds faster $\left(\chi^{2}=7.8, \mathrm{df}=1, \mathrm{P}=0.005\right)$ and had a higher space use $\left(F_{1,285}=4.33, \mathrm{P}=0.038\right)$ than males. Treatment had no significant effect on the proportion of individuals consuming seeds $\left(\chi^{2}=3.91, \mathrm{df}=3, \mathrm{P}=0.27\right)$, the latency to first seed acceptance $\left(\chi^{2}=1.99, \mathrm{df}=3, \mathrm{P}=0.57\right.$, Fig. 2A), the mean amount of seeds consumed $\left(\chi^{2}=5.10, \mathrm{df}=6, \mathrm{P}=0.53\right.$, Fig. $\left.2 \mathrm{~B}\right)$, seed handling time $\left(\chi^{2}=3.46, \mathrm{df}=3, \mathrm{P}=\right.$ $0.32)$ and space use $\left(F_{1,283}=0.73, \mathrm{P}=0.53\right)$.

For comparison, identical analyses conducted on $H$. affinis and reported in Charalabidis et al. (2017) were as follows. Irrespective of treatment, H. affinis females 
consumed more seeds than males $\left(\chi^{2}=16.45\right.$, df $\left.=1, \mathrm{P}<0.001\right)$. A treatment effect was observed on the proportion of individuals consuming weeds $\left(\chi^{2}=10.62\right.$, df $\left.=3, P=0.014\right)$, the latency to first seed consumption $\left(\chi^{2}=12.6, \mathrm{df}=3, \mathrm{P}<0.001\right.$, Fig. $\left.2 \mathrm{~A}\right)$, the total number of seeds consumed $\left(\chi^{2}=17.22, \mathrm{df}=6, \mathrm{P}=0.0085\right.$, Fig. $\left.2 \mathrm{~B}\right)$. More individuals consumed weed seeds with predator cues than in the control $(\mathrm{P}=0.0025$, odds-ratio $=2.94,95 \% \mathrm{CI}=[1.49$, 5.79]. Latency was lower with predator cues than in the other treatments (control: $P<0.001$, hazard ratio $=2.22,95 \% \mathrm{CI}=[1.38,3.56]$; intraspecific competition: $\mathrm{P}=0.032$, hazard ratio $=$ $1.59,95 \% \mathrm{CI}=[1.02,2.47]$; interspecific competition: $\mathrm{P}=0.020$, hazard ratio $=1.67,95 \% \mathrm{CI}$ $=[1.08,2.57]$, Fig. 2A). H. affinis consumed more seeds with predator cues than in the other treatments (control $\mathrm{P}=0.030$; intraspecific competition $\mathrm{P}=0.031$; interspecific competition $\mathrm{P}$ $=0.019$ (Fig. 2B)) with a sex effect $\left(\chi^{2}=6.58, \mathrm{df}=2, \mathrm{P}=0.037\right)$, but no interaction between sex and treatment $\left(\chi^{2}=1.47, \mathrm{df}=6, \mathrm{P}=0.96\right)$. Handling time did not vary with treatment $\left(\chi^{2}=\right.$ $1.40, \mathrm{df}=3, \mathrm{P}=0.71)$. Space use differed between treatments $\left(F_{3,257}=3.95, \mathrm{P}=0.0088\right)$ and was higher under interspecific competition than under intraspecific competition $\left(F_{3,257}=\right.$ $3.36, \mathrm{P}=0.019)$

There was an effect of carabid species and treatment on the proportion of individuals consuming seeds $\left(\chi^{2}=8.82, \mathrm{df}=3, \mathrm{P}=0.032\right)$. More individuals of $P$. cupreus consumed seeds in the control $\left(\chi^{2}=24.44, \mathrm{df}=1, \mathrm{P}<0.001\right)$, intraspecific competition $\left(\chi^{2}=4.45, \mathrm{df}=1\right.$, $\mathrm{P}=0.035)$ and interspecific competition treatments than $H$. affinis $\left(\chi^{2}=15.77\right.$, df $=1, \mathrm{P}$ $<0.001)$. There was no significant difference in seed consumption by the two carabid species under predation $\left(\chi^{2}=1.31, \mathrm{df}=1, \mathrm{P}=0.25\right)$. Latency to first seed acceptance differed between the two carabid species $\left(\chi^{2}=8.14, \mathrm{df}=3, \mathrm{P}=0.043\right)$. $P$. cupreus started consuming seeds earlier than H. affinis in all four treatments (control: $\chi^{2}=28.76$, $\mathrm{df}=1, \mathrm{P}<0.001$; intraspecific competition: $\chi^{2}=4.51, \mathrm{df}=1, \mathrm{P}=0.034$; interspecific competition: $\chi^{2}=22.66$, df $=1, \mathrm{P}<$ 0.001 and predation: $\chi^{2}=4.51, \mathrm{df}=1, \mathrm{P}=0.034$ ). Moreover, across treatments $P$. cupreus 
individuals spent more time handling seeds of $T$. officinale than individuals of $H$. affinis $\left(\chi^{2}{ }_{1}=\right.$ 33.60, $\mathrm{df}=1, \mathrm{P}<0.001$, results for the control: $\chi^{2}=8.46$, $\mathrm{df}=1, \mathrm{P}=0.0036$; predation: $\chi^{2}=$ 12.60, $\mathrm{df}=1, \mathrm{P}<0.001$; intraspecific competition: $\chi^{2}=7.65, \mathrm{df}=1, \mathrm{P}=0.0057$; interspecific competition: $\chi^{2}=4.45$, $\left.\mathrm{df}=1, \mathrm{P}=0.035\right)$. There was no interaction between carabid species and treatment $\left(\chi^{2}=2.26\right.$, df $\left.=3, P=0.52\right)$. The proportion of space used did not differ between the two carabid species $\left(F_{1,543}=3.06, \mathrm{P}=0.08\right)$. There was no interaction between carabid species and treatment $\left(F_{3,540}=0.51, \mathrm{P}=0.67\right)$.

\section{Discussion}

\section{Seed acceptance for four weed species}

Poecilus cupreus and $H$. affinis differed in their relative acceptance for the four weed species, with subsequent differences in seed diet breadth. Poecilus cupreus exhibited a high level of seed acceptance for T. officinale and S. vulgaris seeds. Individuals accepted seeds earlier and ate more seeds, and a higher total proportion of individuals consumed seeds. This high acceptance by $P$. cupreus for $T$. officinale and $S$. vulgaris might be explained by their ease of consumption. Conversely, the other two weed species were less accepted. We observed that $P$. cupreus individuals had difficulties handling seeds of $V$. arvensis and often lost these seeds; as a result, the initial interest of $P$. cupreus in $V$. arvensis declined dramatically after the first hour of the experiment, i.e. these seeds were subsequently discarded. The same behaviour was observed for seeds of C. bursa-pastoris. Ease of consumption could be explained by an allometric compatibility between the size of the mandibles of the carabid and the size of the seed species (Honěk, Martinkova, Saska, \& Pekar, 2007). P. cupreus individuals might be too large (in comparison to $H$. affinis) to consume $V$. arvensis but can handle well seeds of $T$. officinale that are twice as long as those 
of $V$. arvensis for the same weight. The lack of interest of $P$. cupreus individuals in seeds of $V$. arvensis might also be explained by the lower digestibility of $V$. arvensis seeds (Hengeveld, 1987; Lundgren \& Lehman, 2010; Schmid, Lehman, Brözel, \& Lundgren, 2014). In contrast, the granivore $H$. affinis consumed all seed species similarly, with equal levels of seed acceptance. Harpalini species have been described as unspecialized feeders of seeds (Acorn \& Ball, 1991; Forsythe, 1983; Kulkarni et al., 2015; Zetto Brandmayr, Giglio, Marano, \& Brandmayr, 1998) and Harpalus sp. have evolved broad mandibles with massive adductors that are able to readily crush seeds (Paarmann, Faust, Arndt, Lüchtrath, \& Rohe, 2006; Zetto Brandmayr et al., 1998). The greater ability of $H$. affinis to consume seeds, as compared to $P$. cupreus, is illustrated by a markedly different handling time for $T$. officinale, a weed otherwise preferred by $P$. cupreus. While $P$. cupreus consumed more seeds of $T$. officinale in total than $H$. affinis did, $P$. cupreus individuals had longer handling times for seeds of this weed. The ability of $H$. affinis individuals to feed on several species of seeds, regardless of their shape or size, is a benefit for a granivore, which subsists predominantly on seeds (Kamenova, Leroux, Polin, \& Plantegenest, 2017) and requires these food items throughout its period of activity. Discarding seeds might result in strong opportunity costs (Stephens, 2008) either because of competition (Dechaume-Moncharmont et al., 2016) or because uneaten seeds enter the seed bank and become unavailable. Our study also showed that $H$. affinis was much slower at commencing the consumption of weed seeds than $P$. cupreus. During the first five hours of the first experiment, $P$. cupreus accepted their first seed earlier and ate significantly more seeds than $H$. affinis, irrespective of the weed species, and a similar pattern was observed in the control treatment of the predator cue experiment. This apparent lower initial interest for seeds by $H$. affinis is unlikely to be due to the weed species offered, as these weed species have been found to be 'preferred' by $H$. affinis in multiple choice-test studies (Honěk, Martinkova, \& Saska, 2011; Honěk et al., 2007; Honěk, Saska, \& 
Martinkova, 2006; Petit et al., 2014; Saska, Martinkova, \& Honěk, 2010). Rather, the pattern might simply result from a lower activity in $H$. affinis than in P. cupreus (Thiele, 1977). Smaller species, such as $H$. affinis have been found to be less active than larger species like $P$. cupreus (Greenslade, 1964; A. Lang, 2000; Luff, 1975). We also observed that most H. affinis individuals sought shelter and hid during the first experiment, with subsequently less time to forage actively for seeds.

\section{Response to predator and competitive cues}

As hypothesized, we detected contrasting responses to competitor and predator cues in the two carabid species. $P$. cupreus did not adjust its level of seed acceptance when facing predator cues. Conversely, $H$. affinis significantly increased its level of seed acceptance in the presence of predator cues, with individuals reducing their latency to first seed acceptance by half and almost doubling their mean seed consumption in comparison to the control treatment. This is consistent with other research showing an increase in seed acceptance in carabids exposed to predator cues (Blubaugh et al., 2017) and with the hypothesis that predator cues could increase acceptance of a food item (Leaver \& Daly, 2003; Metcalfe et al., 1987; Perea, González, San Miguel, \& Gil, 2011). In situations of predatory interference, individuals would tend to reduce the effort or energy used to assess a resource and therefore accept more of the encountered food items, irrespective of their quality. This ability to adjust feeding item acceptance when faced with a predation risk would enable $H$. affinis to maintain its feeding income, especially in arable situations where carabid predators such $P$. melanarius are common and abundant. In contrast, situations of intraspecific and interspecific competition triggered no behavioural adjustment in $H$. affinis, even if competition could expose individuals to the loss of reasonably good quality resource items (Dechaume-Moncharmont et al., 2016). 

may be related to its status as an obligate omnivore. Since $P$. cupreus can rely on both plant and animal prey we can speculate that under predation, individuals might always be able to switch to other food types that are not shared with the competitor, thus not requiring to

421 increase their seed acceptance in order to maintain their energetic income. We would have 422 expected a change in seed acceptance in response to a predation risk, since an encounter with a potential predator is more directly lethal than the opportunity costs resulting from competition. It is possible that $P$. cupreus perceived the olfactory cues of $P$. melanarius as cues of a potential feeding competitor, rather than that of a predator, as both species can act as carnivores (Brooks et al., 2012) and consume seeds (Lundgren, 2009). It is also possible that the interest of $P$. cupreus in $T$. officinale seeds in the control treatment was already as high as possible, with individuals consuming any available seeds quickly and to satiety. Finally, we cannot exclude the possibility that while olfactory cues have proved useful to induce behavioural response in carabids (Guy et al., 2008), P. cupreus does not rely on olfactory cues alone to assess risks, but may rather rely on mechanical cues (Kratina, Vos, Bateman, \& Anholt, 2009). Hence, individuals may have not perceived odours as effective cues of risks in our study.

\section{Implications of contrasted foraging strategies for weed biocontrol}

The present study focused on two carabid species, an obligate omnivore and a granivore and provides evidence that the two species exhibit different seed foraging strategies. Although the two strategies described here cannot be generalised to the trophic guild level, the two carabid species tested here are the two most abundant species and often co-occur within carabid communities sampled regionally. As such, and provided that the strategies we observed in controlled conditions apply in field conditions, one can speculate that the two foraging 
strategies described here could coexist in arable fields. Although we observed that the two strategies overlap, as shown by the shared high interest of $P$. cupreus and H. affinis for dandelion seeds, they would also appear quite complementary in terms of the respective 445

ranges of seed species eaten, and in terms of timing of seed consumption. Future studies characterizing the foraging strategies of granivore and obligate omnivore carabid species should assess whether the two strategies described here are generic and/or if other foraging strategies exist in seed-eating carabid beetles. Gaining such knowledge would enable scientists to test for potential behaviourally-based niche complementarity in seed-eating carabid assemblages and to quantify its effect on seed suppression.

\section{Acknowledgements}

The authors would like to thank the staff of the INRA Epoisses experimental farm. We also wish to thank the staff at INRA Dijon for their technical support. This work was supported by the ANR PEERLESS (ANR-12-Agro-0006) and the ANR AGROBIOSE (ANR-13-Agro0001). The PhD of Alice Charalabidis was funded by INRA and the Region of Burgundy Franche-Comté.

Appendix A. Supplementary data

Supplementary data associated with this article can be found, in the online version, at XXXXX." 


\section{References}

Acorn, J. H., \& Ball, G. E. (1991). The mandibles of some adult ground beetles: structure, function, and the evolution of herbivory (Coleoptera: Carabidae). Canadian Journal of Zoology, 69(3), 638-650. https://doi.org/10.1139/z91-094

Amita, H., Kawamori, A., \& Matsushima, T. (2010). Social influences of competition on impulsive choices in domestic chicks. Biology Letters, 6(2), 183-186. https://doi.org/10.1098/rsbl.2009.0748

Armsworth, C. G., Bohan, D. A., Powers, S. J., Glen, D. M., \& Symondson, W. O. C. (2005). Behavioural responses by slugs to chemicals from a generalist predator. Animal Behaviour, 69(4), 805-811. https://doi.org/10.1016/j.anbehav.2004.07.009

Blubaugh, C. K., Widick, I. V., \& Kaplan, I. (2017). Does fear beget fear? Risk-mediated habitat selection triggers predator avoidance at lower trophic levels. Oecologia, 185(1). https://doi.org/10.1007/s00442-017-3909-1

Bohan, D. A., Boursault, A., Brooks, D. R., \& Petit, S. (2011). National-scale regulation of the weed seedbank by carabid predators. Journal of Applied Ecology, 48(4), 888-898. https://doi.org/10.1111/j.1365-2664.2011.02008.x

Brooks, D. R., Storkey, J., Clark, S. J., Firbank, L. G., Petit, S., \& Woiwod, I. P. (2012). Trophic links between functional groups of arable plants and beetles are stable at a national scale. Journal of Animal Ecology, 81(1), 4-13. https://doi.org/10.1111/j.13652656.2011.01897.x

Carmona, D. M., \& Landis, D. A. (1999). Influence of Refuge Habitats and Cover Crops on Seasonal Activity-Density of Ground Beetles (Coleoptera: Carabidae) in Field Crops. Environmental Entomology, 28(6), 1145-1153. https://doi.org/10.1093/ee/28.6.1145

Carstensen, B., Plummer, M., Laara, E., Hills, M., (2017). Epi: A package for statistical analysis in epidemiology. $\mathrm{R}$ package version 2.11. URL: https://CRAN.Rproject.org/package $=$ Epi

Charalabidis, A., Dechaume-Moncharmont, F.-X., Petit, S., \& Bohan, D. A. (2017). Risk of predation makes foragers less choosy about their food. PLoS ONE, 12(11), e0187167. https://doi.org/10.1371/journal.pone.0187167

Cribari-Neto, F., \& Zeileis, A., (2010). Beta regression in R. Journal of statistical software 34(2), 1-24. URL: http://www.jstatsoft.org/v34/i02/.

Crowder, D. W., \& Jabbour, R. (2014). Relationships between biodiversity and biological control in agroecosystems: Current status and future challenges. Biological Control, 75, 8-17. https://doi.org/10.1016/j.biocontrol.2013.10.010

Currie, C. R., Spence, J. R., \& Niemelä, J. K. (1996). Competition, cannibalism and intraguild predation among ground beetles (Coleoptera: Carabidae): A laboratory study. The Coleopterists Bulletin, 50(2), 135-148. https://doi.org/10.1649/0010-065X-65.1.91

Davis, J. M., Nufio, C. R., \& Papaj, D. R. (2011). Resource quality or competition: why increase resource acceptance in the presence of conspecifics? Behavioral Ecology, 22(4), 730-737. https://doi.org/10.1093/beheco/arr042

Dechaume-Moncharmont, F.-X., Brom, T., \& Cézilly, F. (2016). Opportunity costs resulting 
from scramble competition within the choosy sex severely impair mate choosiness. Animal Behaviour, 114, 249-260. https://doi.org/10.1016/j.anbehav.2016.02.019

Dechaume Moncharmont, F.-X., Decourtye, A., Hennequet-Hantier, C., Pons, O., \& PhamDelègue, M.-H. (2003). Statistical analysis of honeybee survival after chronic exposure to insecticides. Environmental Toxicology and Chemistry, 22(12), 3088. https://doi.org/10.1897/02-578

Deroulers, P., \& Bretagnolle, V. (2018). The consumption pattern of 28 species of carabid beetles ( Carabidae) to a weed seed, Viola arvensis. Bulletin of Entomological Research, 1-7. http://doi.org/10.1017/S0007485318000457

Diehl, E., Wolters, V., \& Birkhofer, K. (2012). Arable weeds in organically managed wheatfields foster carabid beetles by resource- and structure-mediated effects. Arthropod-Plant Interactions, 6(1), 75-82. https://doi.org/10.1007/s11829-011-9153-4

Diekötter, T., Wamser, S., Dörner, T., Wolters, V., \& Birkhofer, K. (2016). Organic farming affects the potential of a granivorous carabid beetle to control arable weeds at local and landscape scales. Agricultural and Forest Entomology, 18(2), 167-173. https://doi.org/10.1111/afe.12150

Dougherty, L. R., \& Shuker, D. M. (2014). Precopulatory sexual selection in the seed bug Lygaeus equestris: a comparison of choice and no-choice paradigms. Animal Behaviour, 89, 207-214. https://doi.org/10.1016/j.anbehav.2014.01.005

Edward, D. A. (2014). The description of mate choice. Behavioral Ecology, 26(2), 301-310. https://doi.org/10.1093/beheco/aru142

Forsythe, T. G. (1983). Mouthparts and feeding of certain ground beetles (Coleoptera: Carabidae). Zoological Journal of the Linnean Society, 79(4), 319-376. https://doi.org/10.1111/j.1096-3642.1983.tb01170.x

Frank, S. D., Shrewsbury, P. M., \& Denno, R. F. (2011). Plant versus prey resources: Influence on omnivore behavior and herbivore suppression. Biological Control, 57(3), 229-235. https://doi.org/10.1016/j.biocontrol.2011.03.004

Gaines, H. R., \& Gratton, C. (2010). Seed predation increases with ground beetle diversity in a Wisconsin (USA) potato agroecosystem. Agriculture, Ecosystems \& Environment, 137(3-4), 329-336. https://doi.org/10.1016/j.agee.2010.03.003

Greenslade, P. J. M. (1964). Pitfall trapping as a method for studying populations of carabidae (Coleoptera). Journal of Animal Ecology, 33(2), 301-310.

Griffith, D. M., \& Poulson, T. L. (1993). Mechanisms and Consequences of Intraspecific Competition in a Carabid Cave Beetle. Ecology, 74(5), 1373-1383.

Guy, A.G., Bohan, D.A., Powers, S. J., \& Reynolds, A. M. (2008). Avoidance of conspecific odour by carabid beetles: a mechanism for the emergence of scale-free searching patterns. Animal Behaviour, $\quad$ 76(3), 585-591. http://doi.org/10.1016/j.anbehav.2008.04.004

Hengeveld, R. (1979). The analysis of spatial patterns of some ground beetles (Col. Carabidae). In Spatial and Temporal Analysis In Ecology. Eds. R. M. Cormack and J. K. ord, pp. 333-346. Maryland, USA: International Co-operative Publishing house.

Hengeveld, R. (1987). Scales of variation: their distinction and ecological importance. 
Hines, J., van der Putten, W. H., De Deyn, G. B., Wagg, C., Voigt, W., Mulder, C., ... Eisenhauer, N. (2015). Towards an integration of biodiversity-ecosystem functioning and food web theory to evaluate relationships between multiple ecosystem services. In Advances in Ecological Research (1st ed., Vol. 53, pp. 161-199). Elsevier Ltd. https://doi.org/10.1016/bs.aecr.2015.09.001

Honek, A., Martinkova, Z., \& Saska, P. (2011). Effect of size, taxonomic affiliation and geographic origin of dandelion (Taraxacum agg.) seeds on predation by ground beetles (Carabidae, Coleoptera). Basic and Applied Ecology, 12(1), 89-96. https://doi.org/10.1016/j.baae.2010.11.003

Honek, A., Martinkova, Z., Saska, P., \& Pekar, S. (2007). Size and taxonomic constraints determine the seed preferences of Carabidae (Coleoptera). Basic and Applied Ecology, 8(4), 343-353. https://doi.org/10.1016/j.baae.2006.07.002

Honek, A., Saska, P., \& Martinkova, Z. (2006). Seasonal variation in seed predation by adult carabid beetles. Entomologia Experimentalis et Applicata, 118(2), 157-162. https://doi.org/10.1111/j.1570-7458.2006.00376.x

Hough-Goldstein, J. A., Vangessel, M. J., \& Wilson, A. P. (2004). Manipulation of Weed Communities to Enhance Ground-Dwelling Arthropod Populations in HerbicideResistant Field Corn. Environmental Entomology, 33(3), 577-586. https://doi.org/10.1603/0046-225X-33.3.577

Ibrahim, A. A., \& Huntingford, F. A. (1989). Laboratory and field studies of the effect of predation risk on foraging in three-spined sticklebacks (Gasterosteus aculeatus). Behaviour, 109(1/2), 46-57.

Jackman Simon (2015). pscl: Classes and Methods for R Developed in the Political Science Computational Laboratory, Stanford University. Department of Political Science,Stanford University. Stanford, California. $\mathrm{R}$ packageversion 1.4.9. URLhttp://pscl.stanford.edu/

Jennions, M. D., \& Petrie, M. (1997). Variation in mate choice and mating preferences: a review of causes and consequences. Biological Reviews of the Cambridge Philosophical Society, 72(2). https://doi.org/10.1017/S0006323196005014

Jonason, D., Smith, H. G., Bengtsson, J., \& Birkhofer, K. (2013). Landscape simplification promotes weed seed predation by carabid beetles (Coleoptera: Carabidae). Landscape Ecology, 28(3), 487-494. https://doi.org/10.1007/s10980-013-9848-2

Kamenova, S., Leroux, C., Polin, S. E., \& Plantegenest, M. (2017). Community-wide stable isotope analysis reveals two distinct trophic groups in a service-providing carabid community. Bulletin of Entomological Research, 1-10. https://doi.org/10.1017/S0007485317000542

Kratina, P., Vos, M., Bateman, A., \& Anholt, B. R. (2009). Functional responses modified by predator density. Oecologia, 159(2), 425-433. https://doi.org/10.1007/s00442-008-12255

Kulkarni, S. S., Dosdall, L. M., \& Willenborg, C. J. (2015). The Role of Ground Beetles (Coleoptera: Carabidae) in Weed Seed Consumption: A Review. Weed Science, 63(02), 355-376. https://doi.org/10.1614/WS-D-14-00067.1 
Lakens, D. (2013). Calculating and reporting effect sizes to facilitate cumulative science: a practical primer for t-tests and ANOVAs. Frontiers in Psychology, 4. https://doi.org/10.3389/fpsyg.2013.00863

Lang, A. (2000). The pitfalls of pitfalls: A comparison of pitfall trap catches and absolute density estimates of epigeal invertebrate predators in arable land. Anzeiger Fur Schadlingskunde, 73(4), 99-106. https://doi.org/10.1007/BF02956438

Lang, B., Rall, B. C., \& Brose, U. (2012). Warming effects on consumption and intraspecific interference competition depend on predator metabolism. Journal of Animal Ecology, 81(3), 516-523. https://doi.org/10.1111/j.1365-2656.2011.01931.x

Larrinaga, A. R. (2010). A univariate analysis of variance design for multiple-choice feedingpreference experiments: A hypothetical example with fruit-eating birds. Acta Oecologica, 36(1), 141-148. https://doi.org/10.1016/j.actao.2009.11.003

Law, J. J., \& Gallagher, R. S. (2015). The role of imbibition on seed selection by Harpalus $\begin{array}{lllll}\text { pensylvanicus. } & \text { Applied } & \text { Soil }\end{array}$ https://doi.org/10.1016/j.apsoil.2014.11.015

Leaver, L. A., \& Daly, M. (2003). Effect of predation risk on selectivity in heteromyid rodents. Behavioural Processes, 64(1), 71-75. https://doi.org/10.1016/S03766357(03)00108-6

Loreau, M. (2001). Biodiversity and Ecosystem Functioning: Current Knowledge and Future Challenges. Science, 294(5543), 804-808. https://doi.org/10.1126/science.1064088

Luff, M. L. (1975). Some features influencing the efficience pitfall traps. Oecologia, 19, 345357. https://doi.org/10.1007/BF00348110

Lundgren, J. G. (2009). Relationships of natural enemies and non-prey foods. Springer Science \& Business Media.

Lundgren, J. G., \& Lehman, R. M. (2010). Bacterial Gut Symbionts Contribute to Seed Digestion in an Omnivorous Beetle. PLoS ONE, 5(5), e10831. https://doi.org/10.1371/journal.pone.0010831

Menalled, F. D., Smith, R. G., Dauer, J. T., \& Fox, T. B. (2007). Impact of agricultural management on carabid communities and weed seed predation. Agriculture, Ecosystems \& Environment, 118(1-4), 49-54. https://doi.org/10.1016/j.agee.2006.04.011

Metcalfe, N. B., Huntingford, F. A., \& Thorpe, J. E. (1987). Predation risk impairs diet selection in juvenile salmon. Animal Behaviour, 35(3), 931-933.

Murray, T. J., Withers, T. M., \& Mansfield, S. (2010). Choice versus no-choice test interpretation and the role of biology and behavior in parasitoid host specificity tests. Biological Control, 52(2), 153-159. https://doi.org/10.1016/j.biocontrol.2009.10.003

Nakagawa, S., \& Cuthill, I. C. (2007). Effect size, confidence interval and statistical significance: A practical guide for biologists. Biological Reviews, 82(4), 591-605. https://doi.org/10.1111/j.1469-185X.2007.00027.x

O’Rourke, M. E., Heggenstaller, A. H., Liebman, M., \& Rice, M. E. (2006). Post-dispersal weed seed predation by invertebrates in conventional and low-external-input crop rotation systems. Agriculture, Ecosystems \& Environment, 116(3-4), 280-288. https://doi.org/10.1016/j.agee.2006.02.018 
Paarmann, W., Faust, N., Arndt, E., Lüchtrath, I., \& Rohe, W. (2006). Constant seed size and mandible growth - a fundamental problem for granivorous ground beetle larvae (Coleoptera: Carabidae). Entomologica Fennica, 17(October), 334-339.

Perea, R., González, R., San Miguel, A., \& Gil, L. (2011). Moonlight and shelter cause differential seed selection and removal by rodents. Animal Behaviour, 82(4), 717-723. https://doi.org/10.1016/j.anbehav.2011.07.001

Petit, S., Boursault, A., \& Bohan, D. A. (2014). Weed seed choice by carabid beetles (Coleoptera: Carabidae): Linking field measurements with laboratory diet assessments. European Journal of Entomology, 111(5), 1-6. https://doi.org/10.14411/eje.2014.086

Petit, S., Trichard, A., Biju-Duval, L., McLaughlin, Ó. B., \& Bohan, D. A. (2017). Interactions between conservation agricultural practice and landscape composition promote weed seed predation by invertebrates. Agriculture, Ecosystems \& Environment, 240, 45-53. https://doi.org/10.1016/j.agee.2017.02.014

R Development Core Team, (2016) R: A language and environment for statistical computing. $\mathrm{R}$ Foundation for Statistical Computing. Vienna, Austria. Available online at http://www.R-project.org.)

Raffa, K. F., Havill, N. P., \& Nordheim, E. V. (2002). How many choices can your test animal compare effectively? Evaluating a critical assumption of behavioral preference tests. Oecologia, 133(3), 422-429. https://doi.org/10.1007/s00442-002-1050-1

Reinhold, K., \& Schielzeth, H. (2014). Choosiness, a neglected aspect of preference functions: a review of methods, challenges and statistical approaches. Journal of Comparative Physiology A, 201(1), 171-182. https://doi.org/10.1007/s00359-014-0963-6

Rodriguez, R. L., \& Greenfield, M. D. (2003). Genetic Variance and Phenotypic Plasticity in a Component of Female Mate Choice in an Ultrasonic Moth. Evolution, 57(6), 13041313.

Rothbart, M. M., \& Hennig, R. M. (2012). Calling song signals and temporal preference functions in the cricket Teleogryllus leo. Journal of Comparative Physiology A, 198(11), 817-825. https://doi.org/10.1007/s00359-012-0751-0

Saska, P., \& Jarošík, V. (2001). Laboratory study of larval food requirements in nine species of Amara (Coleoptera: Carabidae). Plant Protection Science, 37(3), 103-110.

Saska, P., Martinkova, Z., \& Honek, A. (2010). Temperature and rate of seed consumption by ground beetles (Carabidae). Biological Control, 52(2), 91-95. https://doi.org/10.1016/j.biocontrol.2009.07.016

Schmid, R. B., Lehman, R. M., Brözel, V. S., \& Lundgren, J. G. (2014). An indigenous gut bacterium, Enterococcus faecalis (Lactobacillales: Enterococcaceae), increases seed consumption by Harpalus pensylvanicus (Coleoptera : Carabidae). Florida Entomologist, 97(2), 575-584. https://doi.org/10.1653/024.097.0232

Stephens, D. W. (2008). Decision ecology: Foraging and the ecology of animal decision making. Cognitive, Affective and Behavioral Neuroscience, 8(4), 475-484. https://doi.org/10.3758/CABN.8.4.475

Straub, C. S., Finke, D. L., \& Snyder, W. E. (2008). Are the conservation of natural enemy biodiversity and biological control compatible goals? Biological Control, 45(2), 225237. https://doi.org/10.1016/j.biocontrol.2007.05.013 
Therneau, T. (2015). _A Package for survival analysis in $\mathrm{S}_{-}$. version 2.38, URL: http://CRAN.R-project.org/package=survival.

Thiele, H. V. (1977). Carabid beetles in their environment. Zoophysiology and ecology (Vol. 10). https://doi.org/10.1007/978-3-642-81154-8

Trichard, A., Alignier, A., Biju-Duval, L., \& Petit, S. (2013). The relative effects of local management and landscape context on weed seed predation and carabid functional groups. Basic and Applied Ecology, 14(3), 235-245. https://doi.org/10.1016/j.baae.2013.02.002

Trichard, A., Ricci, B., Ducourtieux, C., \& Petit, S. (2014). The spatio-temporal distribution of weed seed predation differs between conservation agriculture and conventional tillage. Agriculture, Ecosystems and Environment, 188, 40-47. https://doi.org/10.1016/j.agee.2014.01.031

Tylianakis, J. M., \& Romo, C. M. (2010). Natural enemy diversity and biological control: making sense of the context-dependency. Basic and Applied Ecology, 11(8), 657-668. https://doi.org/10.1016/j.baae.2010.08.005

Underwood, A. J., Chapman, M. G., \& Crowe, T. P. (2004). Identifying and understanding ecological preferences for habitat or prey. Journal of Experimental Marine Biology and Ecology, 300(1-2), 161-187. https://doi.org/10.1016/j.jembe.2003.12.006

Zetto Brandmayr, T., Giglio, A., Marano, I., \& Brandmayr, P. (1998). Morphofunctional and ecological features in carabid (Coleoptera) larvae. Mus. Reg. Sci. Nat. Torino, (January), 449-490. 
Table 1. Acceptance of weed seeds without olfactory disturbance: Observed mean and SE per carabid species and sex during the first hour of

700 test for the four species of weeds

\begin{tabular}{|c|c|c|c|c|c|c|c|c|}
\hline & \multicolumn{4}{|c|}{ Poecilus cupreus } & \multicolumn{4}{|c|}{ Harpalus affinis } \\
\hline & \multicolumn{2}{|c|}{ Males } & \multicolumn{2}{|c|}{ Females } & \multicolumn{2}{|c|}{ Males } & \multicolumn{2}{|c|}{ Females } \\
\hline \# individuals tested & 9 & & 9 & & 10 & & 10 & \\
\hline$\%$ individuals consuming & 89 & $( \pm 11)$ & 89 & $( \pm 11)$ & 40 & $( \pm 16)$ & 10 & $( \pm 10)$ \\
\hline Latency 1 st seed (seconds) & 809 & $( \pm 395)$ & 1026 & $( \pm 470)$ & 2455 & $( \pm 489)$ & 3392 & $( \pm 207)$ \\
\hline Mean \# seeds consumed & 5.6 & $( \pm 1)$ & 5.2 & $( \pm 1.1)$ & 3.6 & $( \pm 1.6)$ & 0.4 & $( \pm 0.4)$ \\
\hline Shelter use (\%) & 22 & $( \pm 15)$ & 11 & $( \pm 11)$ & 50 & $( \pm 17)$ & 90 & $( \pm 10)$ \\
\hline \multicolumn{9}{|l|}{ S. vulgaris } \\
\hline \# individuals tested & 9 & & 9 & & 10 & & 10 & \\
\hline$\%$ individuals consuming & 78 & $( \pm 15)$ & 67 & $( \pm 17)$ & 40 & $( \pm 16)$ & 18 & $( \pm 12)$ \\
\hline Latency 1 st seed (seconds) & 1519 & $( \pm 500)$ & 1519 & $( \pm 546)$ & 2502 & $( \pm 496)$ & 3348 & $( \pm 181)$ \\
\hline Mean \# seeds consumed & 6.9 & $( \pm 1.8)$ & 6.7 & $( \pm 2.2)$ & 2.4 & $( \pm 1.2)$ & 0.4 & $( \pm 0.3)$ \\
\hline Shelter use (\%) & 11 & $( \pm 11)$ & 11 & $( \pm 11)$ & 50 & $( \pm 17)$ & 82 & $( \pm 12)$ \\
\hline \multicolumn{9}{|l|}{ V. arvensis } \\
\hline \# individuals tested & 9 & & 9 & & 10 & & 10 & \\
\hline$\%$ individuals consuming & 100 & & 89 & $( \pm 11)$ & 20 & $( \pm 13)$ & 22 & $( \pm 15)$ \\
\hline Latency 1 st seed (seconds) & 566 & $( \pm 159)$ & 1186 & $( \pm 362)$ & 3200 & $( \pm 276)$ & 3265 & $( \pm 259)$ \\
\hline Mean \# seed consumed & 3.9 & $( \pm 1.1)$ & 2.3 & $( \pm 0.8)$ & 0.6 & $( \pm 0.3)$ & 0.8 & $( \pm 0.7)$ \\
\hline Shelter use $(\%)$ & 0 & $( \pm 0)$ & 22 & $( \pm 15)$ & 50 & $( \pm 17)$ & 78 & $( \pm 15)$ \\
\hline \multicolumn{9}{|l|}{ C. bursa-pastoris } \\
\hline \# individuals tested & 9 & & 9 & & 10 & & 10 & \\
\hline$\%$ individuals consuming & 33 & $( \pm 17)$ & 22 & $( \pm 15)$ & 20 & $( \pm 13)$ & 10 & $( \pm 10)$ \\
\hline Latency 1 st seed (seconds) & 2531 & $( \pm 538)$ & 3038 & $( \pm 383)$ & 2974 & $( \pm 420)$ & 3563 & $( \pm 37)$ \\
\hline Mean \# seeds consumed & 1.4 & $( \pm 1)$ & 3.1 & $( \pm 2.1)$ & 1.8 & $( \pm 1.2)$ & 0.3 & $( \pm 0.3)$ \\
\hline Shelter use (\%) & 11 & $( \pm 11)$ & 22 & $( \pm 15)$ & 60 & $( \pm 16)$ & 80 & $( \pm 13)$ \\
\hline
\end{tabular}

$\%$ individuals consuming

Shelter use (\%)

11

$( \pm 11)$

$( \pm 15)$

60

$( \pm 16)$

$( \pm 13)$ 
Table 2. Effect of predator and competitor cues on seed acceptance: Observed mean (and SE) per carabid species and sex for each olfactory cues treatment. Values for H. affinis are derived from Charalabidis et al. (2017)

\begin{tabular}{|c|c|c|c|c|c|c|c|c|}
\hline \multirow{3}{*}{ Control } & \multicolumn{4}{|c|}{ Poecilus cupreus } & \multicolumn{4}{|c|}{ Harpalus affinis } \\
\hline & \multicolumn{2}{|c|}{ Males } & \multicolumn{2}{|c|}{ Females } & \multicolumn{2}{|c|}{ Males } & \multicolumn{2}{|c|}{ Females } \\
\hline & & & & & & & & \\
\hline \# individuals tested & 35 & & 36 & & 39 & & 31 & \\
\hline$\%$ individuals consuming & 86 & $( \pm 6)$ & 72 & $( \pm 7)$ & 36 & $( \pm 8)$ & 42 & $( \pm 9)$ \\
\hline Handling time (seconds) & 750 & $( \pm 95)$ & 563 & $( \pm 143)$ & 397 & $( \pm 60)$ & 335 & $( \pm 24)$ \\
\hline Latency 1 st seed (seconds) & 1007 & $( \pm 211)$ & 1617 & $( \pm 246)$ & 2533 & $( \pm 249)$ & 2158 & $( \pm 313)$ \\
\hline Mean \# seed consumed & 3.0 & $( \pm 0.4)$ & 3.3 & $( \pm 0.5)$ & 1.6 & $( \pm 0.5)$ & 2.2 & $( \pm 0.5)$ \\
\hline$\%$ of space used & 62 & $( \pm 4)$ & 74 & $( \pm 3)$ & 64 & $( \pm 3)$ & 67 & $( \pm 3)$ \\
\hline \multicolumn{9}{|l|}{ Intraspecific Competition } \\
\hline \# individuals tested & 36 & & 36 & & 39 & & 32 & \\
\hline$\%$ individuals consuming & 72 & $( \pm 7)$ & 61 & $( \pm 8)$ & 46 & $( \pm 8)$ & 53 & $( \pm 9)$ \\
\hline Handling time (seconds) & 717 & $( \pm 118)$ & 608 & $( \pm 75)$ & 511 & $( \pm 69)$ & 354 & $( \pm 41)$ \\
\hline Latency 1 st seed (seconds) & 1355 & $( \pm 249)$ & 1756 & $( \pm 262)$ & 2090 & $( \pm 278)$ & 1784 & $( \pm 313)$ \\
\hline Mean \# seed consumed & 2.9 & $( \pm 0.4)$ & 2.6 & $( \pm 0.4)$ & 1.2 & $( \pm 0.3)$ & 1.5 & $( \pm 0.4)$ \\
\hline$\%$ of space used & 63 & $( \pm 3)$ & 66 & $( \pm 3)$ & 59 & $( \pm 3)$ & 58 & $( \pm 3)$ \\
\hline \multicolumn{9}{|l|}{ Interspecific Competition } \\
\hline \# individuals tested & 36 & & 36 & & 43 & & 32 & \\
\hline$\%$ individuals consuming & 86 & $( \pm 6)$ & 72 & $( \pm 8)$ & 46 & $( \pm 8)$ & 50 & $( \pm 9)$ \\
\hline Handling time (seconds) & 614 & $( \pm 55)$ & 421 & $( \pm 55)$ & 493 & $( \pm 65)$ & 281 & $( \pm 25)$ \\
\hline Latency 1 st seed (seconds) & 1034 & $( \pm 211)$ & 1418 & $( \pm 245)$ & 2135 & $( \pm 256)$ & 1915 & $( \pm 308)$ \\
\hline Mean \# seed consumed & 3.1 & $( \pm 0.3)$ & 2.7 & $( \pm 0.4)$ & 1.4 & $( \pm 0.3)$ & 2.4 & $( \pm 0.6)$ \\
\hline$\%$ of space used & 67 & $( \pm 3)$ & 70 & $( \pm 3)$ & 67 & $( \pm 3)$ & 71 & $( \pm 3)$ \\
\hline \multicolumn{9}{|l|}{ Predation } \\
\hline \# individuals tested & 36 & & 36 & & 43 & & 31 & \\
\hline$\%$ individuals consuming & 75 & $( \pm 7)$ & 72 & $( \pm 8)$ & 60 & $( \pm 7)$ & 71 & $( \pm 8)$ \\
\hline Handling time (seconds) & 665 & $( \pm 80)$ & 529 & $( \pm 60)$ & 430 & $( \pm 54)$ & 361 & $( \pm 28)$ \\
\hline Latency 1 st seed (seconds) & 1162 & $( \pm 243)$ & 1558 & $( \pm 244)$ & 1527 & $( \pm 261)$ & 1070 & $( \pm 296)$ \\
\hline Mean \# seed consumed & 3.1 & $( \pm 0.4)$ & 2.6 & $( \pm 0.4)$ & 3.0 & $( \pm 0.5)$ & 3.3 & $( \pm 0.7)$ \\
\hline$\%$ of space used & 68 & $( \pm 3)$ & 71 & $( \pm 4)$ & 68 & $( \pm 3)$ & 64 & $( \pm 3)$ \\
\hline
\end{tabular}


Fig. 1. Cumulative number of seeds consumed (bootstrapped $+/-95 \% \mathrm{CI}$ ) by $P$. cupreus (A) and $H$. affinis (B) individuals at each sample date for seeds of $T$. officinale $(\bullet), S$. vulgaris $(\mathbf{\Lambda})$, C. bursa-pastoris $(\mathbf{\square})$ and V. arvensis $(\diamond)$. 
Fig. 2. (A) Mean latency to first seed acceptance (bootstrapped +/- 95\%CI) in each treatment for $H$. affinis $(\diamond)$ and P. cupreus ( $\square$ ), (B) Mean number of seeds consumed (bootstrapped $+/-95 \% \mathrm{CI}$ ) by $H$. affinis $(\diamond)$ and P. cupreus $(\square)$ individuals during the hour of the test in each treatment. The sample sizes are shown above the x-axis. Values for H. affinis are derived from Charalabidis et al. (2017). 


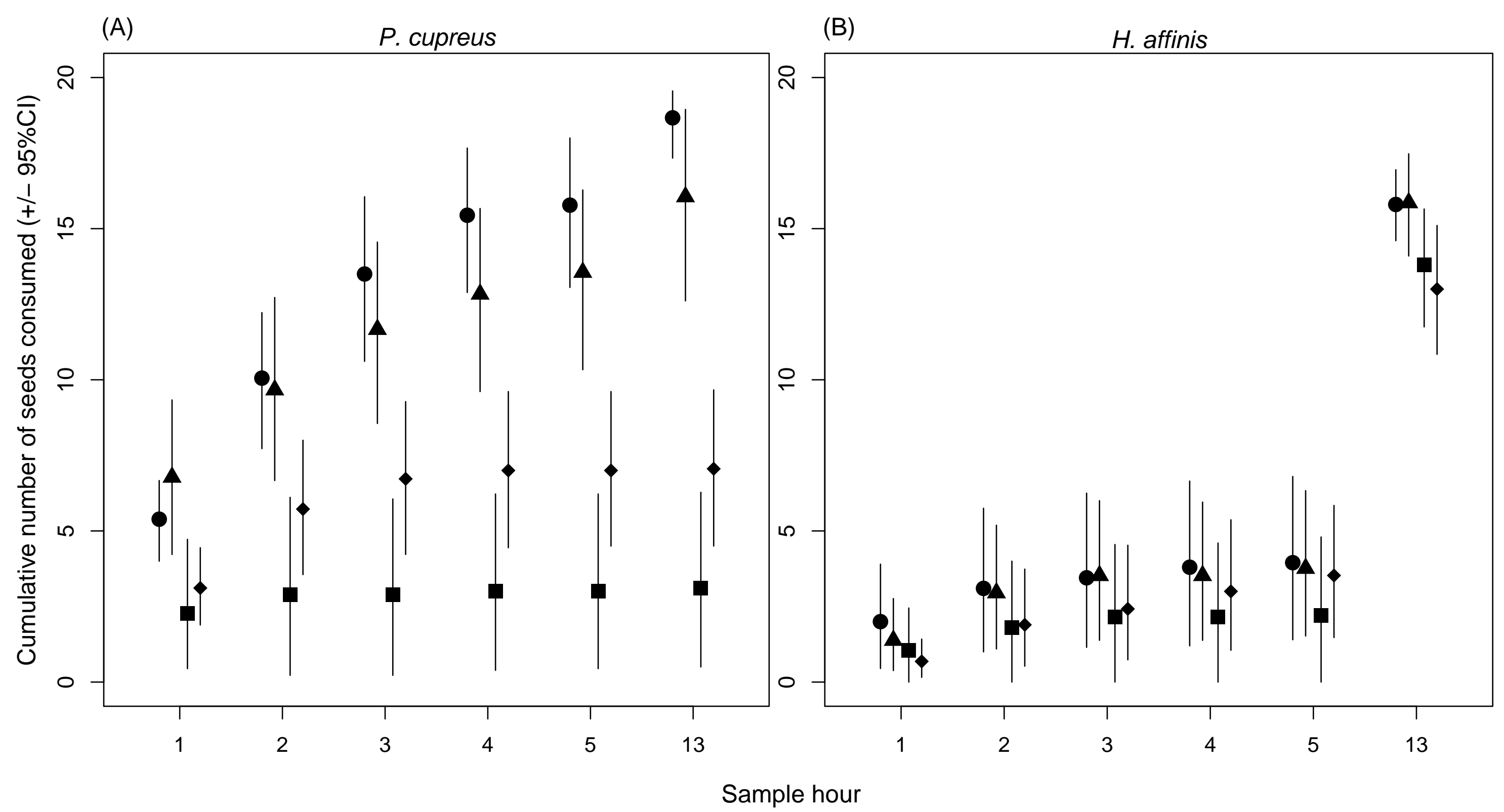


(A)
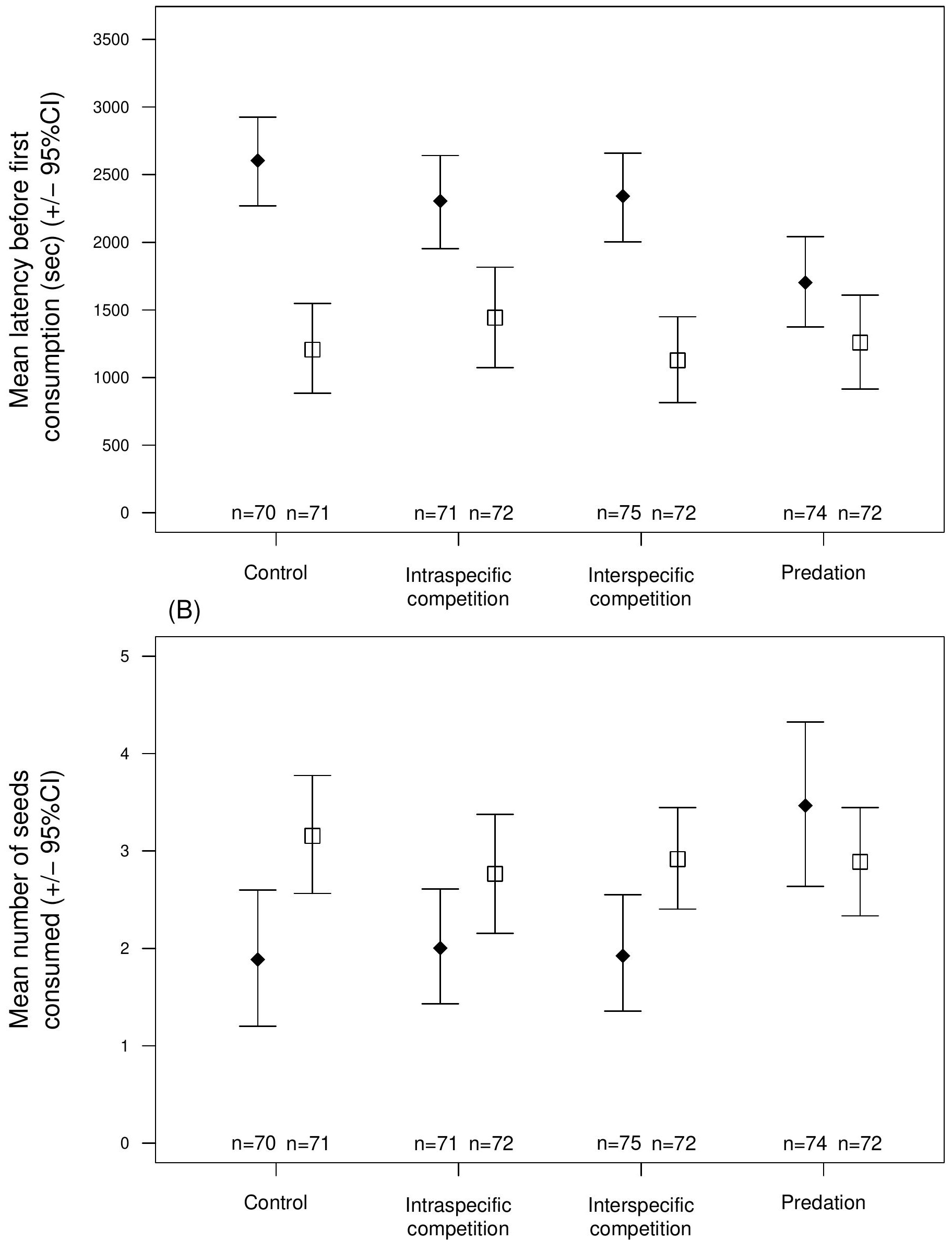